\title{
Process optimization for amylase production of Bacillus subtilis M4 mutant strain
}

\author{
Naranchimeg B., Altantsetseg Kh., Urantulkhuur B.* \\ School of Animal Science and Biotechnology, Mongolian University of Life Sciences, \\ Ulaanbaatar, Mongolia \\ *Corresponding author: urantulkhuur.b@muls.edu.mn
}

\begin{abstract}
There are many factors that influence the character of bacterial metabolism and enzyme production. For the maximum production of the desired products, the media components and fermentation conditions should be optimized. In our investigation, we improved the amylase production of Bacillus subtilis M4 mutant strain by the combination of two optimization techniques. The cultural conditions (time period, temperature, $\mathrm{pH}$, inoculum volume) and medium ingredients (various carbon, organic and inorganic nitrogen sources, chlorides, sulfates, phosphates, carbonates) were optimized by one factor at a time methodology (OFAT) and response surface methodology (RSM) to increase the amylase production. The optimum conditions for amylase production were found be the following: $35^{\circ} \mathrm{C}, \mathrm{pH}$ range 7 and incubation time $72 \mathrm{~h}$, inoculum volume $8 \%$ (v/v). Optimum medium composition for amylase production was the following: starch $12.9 \mathrm{~g}$, peptone 9.75 $\mathrm{g}$, calcium carbonate $0.439 \mathrm{~g}$, magnesium sulfate $0.464 \mathrm{~g}$ and potassium chloride $0.464 \mathrm{~g}$ per liter. When applied to our optimized medium in the fermentation process, the enzyme activity increased from 0.741 to $1.58 \mathrm{U} / \mathrm{ml}$, which means a 2.1 -fold increase compared to the original medium.
\end{abstract}

KEYWORD: Amylase activity, Bacillus spp., Statistical optimization, OFAT, RSM

\section{INTRODUCTION}

Amylases are glycoside hydrolases enzymes, which break starch into glucose, maltose, maltotriose, and dextrin by hydrolyzing process of glycosidic bonds. These enzymes have been widely used many years.First enzyme produced industrially was an amylase from a fungal source in 1894 and used as a pharmaceuticalaid for the treatment of digestive disorders [1]. Amylases are the major class of industrial enzymes, which constitute approximately $25 \%$ of the enzyme market [2]. The biological organisms such as plants, animals, and microorganisms are major sources of enzymes. Microorganism produces amylase more beneficially than other sources. The production rate of microorganisms is high and can be engineered to

\section{MATERIALS AND METHODS}

\section{Microorganism}

B.subtilis M4 mutant strainobtained from physical and chemical mutagenesis in the Biosynthesis laboratory of School of Animal Science and obtain enzymes of good characteristics [3]. The Bacillus genus trends to dominate the enzyme industry, because of almost all microorganisms of this genus synthesis $\alpha$-amylase. Amylases obtained from Bacillus licheniformis, Bacillus stearothermophilus, and Bacillus amyloliquefaciens are used in many industrial processes such as in food, fermentation, textiles and paper industries [4]. The composition and concentration of fermentation media significantly influence bacterial growth and extracellular amylase production. Optimization of cultural conditions is essential for the maximum production of bacterial strains. Almost all forms of microorganisms grow differently with specificity to different substrates in the fermentation medium.
Biotechnology, Mongolian University Of Life Sciences. The strain was kept on slantagar at $4^{\circ} \mathrm{C}$.

\section{Culture condition}

$20 \mathrm{ml}$ of basal media were sterilized and inoculated with $24 \mathrm{~h}$ bacterial slant and incubated in a shaking 
incubator $(110 \mathrm{rpm})$ at $37^{\circ} \mathrm{C}$. When the absorbance of the culture broth reached at A600 nm to 0.15 (cell density about $1 \times 10^{6} \mathrm{CFU} / \mathrm{ml}$ ) was used as a bacterial inoculum. The medium composition was the following: (g/l) starch 10, peptone $6, \mathrm{MgSO}_{4} 0.5, \mathrm{KCl}$ $0.5[6,7]$.

\section{Enzyme production}

The basal media was inoculated with $10 \%\left(1 \times 10^{6}\right.$ $\mathrm{CFU} / \mathrm{ml}$ ) of bacterial inoculum and incubated at $37^{\circ} \mathrm{C}$ for $24 \mathrm{~h}$ in shaking incubator with shaking of 110 rpm. When reached the fermentation period, the culture medium was centrifuged at $5000 \mathrm{rpm}$ for 10 min and supernatant was used as a crude enzyme [8].

\section{Amylase Assay}

Amylase activity was determined by spectrophotometric method according to Fisher and Stein [9]. $1.0 \mathrm{ml}$ of the crude enzyme was taken in a test tube and $1.0 \mathrm{ml}$ of substrate (starch) was added. The test tube was incubated at $45^{\circ} \mathrm{C}$ in the water bath for $30 \mathrm{~min}$. Then $2.0 \mathrm{ml}$ dinitro-salicylic acid reagent was added in the tube and kept in boiling water bath for $5 \mathrm{~min}$. After cooling at room temperature, the absorbance was read at $540 \mathrm{~nm}$ by spectrophotometer. One unit of amylase activity was measured as the amount of amylase required to liberate reducing sugar equivalent to one $\mathrm{mmol}$ of $\mathrm{D}$ glucose per minute at $45^{\circ} \mathrm{C}[10]$.

\section{Bacterial growth}

The growth of bacteria was determined by the optical density of culture broth at $600 \mathrm{~nm}$ ina spectrophotometer. Cells were isolated by centrifugation $\left(5000 \mathrm{rpm}\right.$ for $5 \mathrm{~min}$ at $\left.4^{\circ} \mathrm{C}\right)$ of culture samples and washed two times with saline water $(0.8 \% \mathrm{NaCl})[11]$.

\section{Process Optimization for Amylase Production}

\section{One factor at a time methodology (OFAT)}

\section{Optimization of physicochemical parameters}

The physicochemical parameters of the fermentation process, such as temperature, $\mathrm{pH}$, inoculum volumeand incubation time were optimized. Enzyme activity was measured after incubation of bacterial strain at various temperatures ranging from $20^{\circ} \mathrm{C}$ to $45^{\circ} \mathrm{C}$ and $\mathrm{pH}$ from 3.0 to 10.0 and optimal temperature and $\mathrm{pH}$ were defined. The effect of inoculum volume on $\alpha$-amylase activity was determined by inoculating the basal medium with different inoculum volumes ranging from $2 \%$ to $12 \%$ $(\mathrm{v} / \mathrm{v})$. To determine optimum incubation period, amylase activity and bacterial growth were observed during $120 \mathrm{~h}$ of incubation at the optimal temperature, $\mathrm{pH}$ and inoculum volume. Samples were taken every $24 \mathrm{~h}$ intervals [11].

\section{Effect of different carbon, nitrogen sources and mineral saltson amylase production}

To determine effect of carbon and nitrogen sources on amylase production, different carbon sources (starch, glucose, lactose, dextrose, maltose and sucrose) at 1.0 $\%(\mathrm{w} / \mathrm{v})$ concentration and different nitrogen sources (casein, peptone, yeast extract and ammonium chloride, ammonium nitrate, potassium nitrate, sodium nitrate and ammonium sulfate) at $0.5 \%(\mathrm{w} / \mathrm{v})$ concentration were added to the fermentation medium $[12,15]$. To study the effect of mineral salts on amylase production, chlorides (manganese chloride, barium chloride, sodium chloride, potassium chloride, and magnesium chloride, calcium chloride, ferric chloride and ammonium chloride), sulfates (calcium sulfate, zinc sulfate, ferrous sulfate, magnesium sulfate, manganese sulfate, potassium sulfate and ammonium sulfate), phosphates (ammonium dihydrogen phosphate, dipotassium phosphate, monopotassium phosphate), carbonates (calcium carbonate, sodium carbonate) were employed at $0.05 \%(\mathrm{w} / \mathrm{v})$ concentration [12].

\section{Central composite rotatable design (CCRD)}

In this experiment, we used the Central composite rotatable design method to find more accurate factor values to reach a good response. Five variables were selected from OFAT investigation results to evaluate their effects on amylase activity. We provided RSM analysis based on CCRD. Minitab version 18.1 program developed a five-level-five-variable CCRD with six replicates at the center point $(13,14)$. In total 32 experiments were carried out in triplicate. The coded levels of the independent variables are prescribed in Table 1. Experimental data were analyzed by the response surface regression (RSREG) methodology and the following secondorder polynomial equation was calculated (1):

$$
Y=\beta_{k 0}+\sum_{i=1}^{5} \beta_{k i} x_{i}+\sum_{i=1}^{5} \beta_{k i i} x_{i}^{2}+\sum_{i=1}^{4} \sum_{i=i+1}^{5} \beta_{k i j} x_{i} x j
$$


whereY is the response variable (amylase activity), $\beta_{\mathrm{k} 0}, \beta_{\mathrm{ki}}, \beta_{\mathrm{kii}}$, and $\beta_{\mathrm{kij}}$ are constant coefficients and xi the uncoded independentvariables[16]. MINITAB calculated the optimal values using equation (1).

Levels of the independent variables in CCRD

\begin{tabular}{llcccccc}
\hline \multirow{2}{*}{ № } & \multirow{2}{*}{ Variables } & Symbol & \multicolumn{5}{c}{ Coded levels } \\
\cline { 3 - 7 } & & code & -2 & -1 & 0 & +1 & +2 \\
\hline 1 & Starch $(\mathrm{g} / \mathrm{l})$ & $\mathrm{X}_{1}$ & 5.0 & 10.0 & 15.0 & 20.0 & 25.0 \\
2 & Peptone $(\mathrm{g} / \mathrm{l})$ & $\mathrm{X}_{2}$ & 5.0 & 7.5 & 10.0 & 12.5 & 15.0 \\
3 & $\mathrm{CaCO}_{3}(\mathrm{~g} / \mathrm{l})$ & $\mathrm{X}_{3}$ & 0.1 & 0.3 & 0.5 & 0.7 & 0.9 \\
4 & $\mathrm{MgSO}_{4}(\mathrm{~g} / \mathrm{l})$ & $\mathrm{X}_{4}$ & 0.1 & 0.3 & 0.5 & 0.7 & 0.9 \\
5 & $\mathrm{KCl}(\mathrm{g} / \mathrm{l})$ & $\mathrm{X}_{5}$ & 0.1 & 0.3 & 0.5 & 0.7 & 0.9 \\
\hline
\end{tabular}

Table 1.

\section{Validation of amylase productionin optimized media}

We compared cell growth and amylase production in optimized media with growth and amylase production in basal media to verify our statistical calculation

\section{RESULTS AND DISCUSSION}

To enhance amylase production, we applied two different optimization technique and optimized culture condition and medium composition.

Incubation period: The Incubation period has an essential role in amylase activity. In our study, the incubation period for optimum production of amylase was $72 \mathrm{~h}$ for $B$. subtilis M4. The enzyme activity reached a maximum of $0.799 \mathrm{U} / \mathrm{ml}$ (Fig 1), then decreased to $0.453 \mathrm{U} / \mathrm{ml}$ when the incubation time increased from 72 to 120 hours. Moreira et al. reported that different species of Bacillus have shown a similar cultivation period of $72 \mathrm{~h}$ [17] for maximum amylase production [18]. A oryzae produced the maximum $\alpha$-Amylase at $72 \mathrm{~h}$ of incubation period results. Bacterial cell growth, amylase activity and $\mathrm{pH}$ in the fermentation media were determined every 24 $\mathrm{h}$ to monitor the changes during $120 \mathrm{~h}$ fermentation of $B$. subtilis M4 strain.
[19]. B. amyloliquefaciens reached the optimum $\alpha-$ Amylase activity after fermentation for 72 hours [15]. In our experiment, the optical density of the $B$. subtilis M4 strain reached a maximum also after $72 \mathrm{~h}$ of fermentation (Fig. 1). It was noticed a positive correlation between growth and amylase activity for this strain that indicates the amylase production was growth associated with the B. subtilis M4 strain. Growth kinetics of the isolated Bacillus strain by Mishra and Behera, started lag phase right after inoculation. The stationary phase started from late 48 $\mathrm{h}$ which continued till $72 \mathrm{~h}$ and after that growth declined at $92 \mathrm{~h} \mathrm{[20].}$

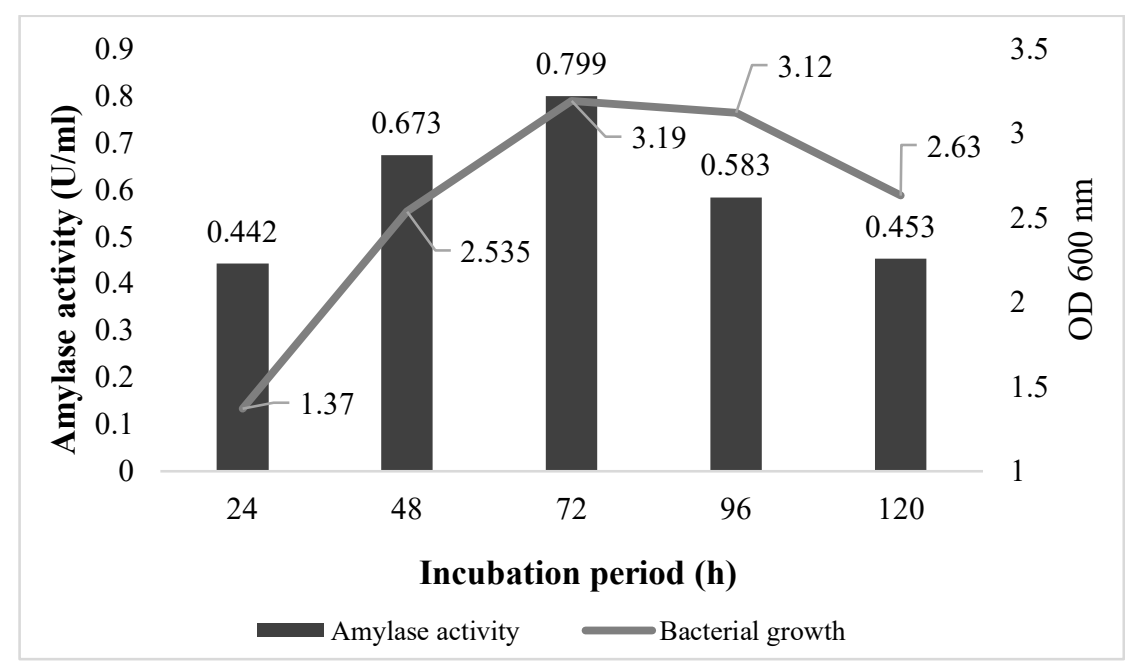

Figure. 1. Amylase activity at different time period 
Temperature: Enzyme activity monitored at various temperatures displayed that $B$. subtilis $\mathrm{M} 4$ reached maximum amylase production at $35^{\circ} \mathrm{C}$ (Fig 2). The optimal temperature of $35^{\circ} \mathrm{C}$ was showed for amylase production by $B$. subtilis CBTK 106, isolated from banana wastes [21]. According to Pokhrel et al., $35^{\circ} \mathrm{C}$ was found as the optimum temperature at which enzyme activity was found to be higher, of the bacterial isolate identified as Bacillus spp. [22].

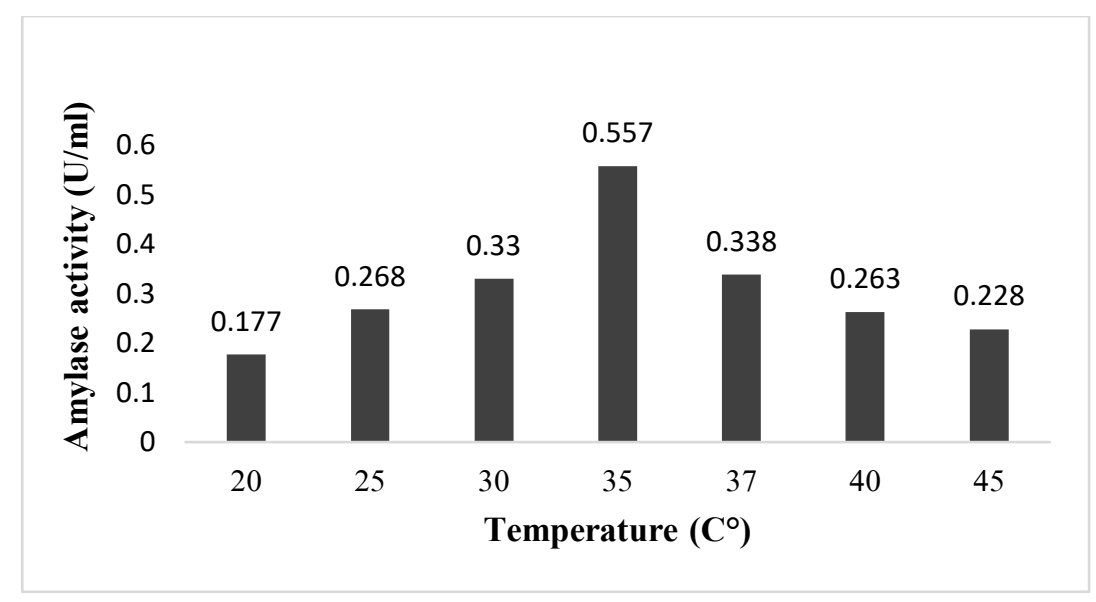

Figure 2. Amylase activity at different temperature

pH: B. subtilis M4 strain was cultured in media of different $\mathrm{pH}$ ranging from 5.0 to 10.0 . The highest enzyme activity was registered in the medium of $\mathrm{pH}$ 7.0(Fig 3).According to Divakaran et al., amylases from Bacillus showed maximum activity at $\mathrm{pH} 7$ [23].
Our results arein good agreement with this study.Behal et al., [24]investigated thermostable amylase producing Bacillus spp that revealed an optimum enzyme activity at $\mathrm{pH} 8.0$ whereas in other species the optimum activity was at $\mathrm{pH} 7.0$ [25].

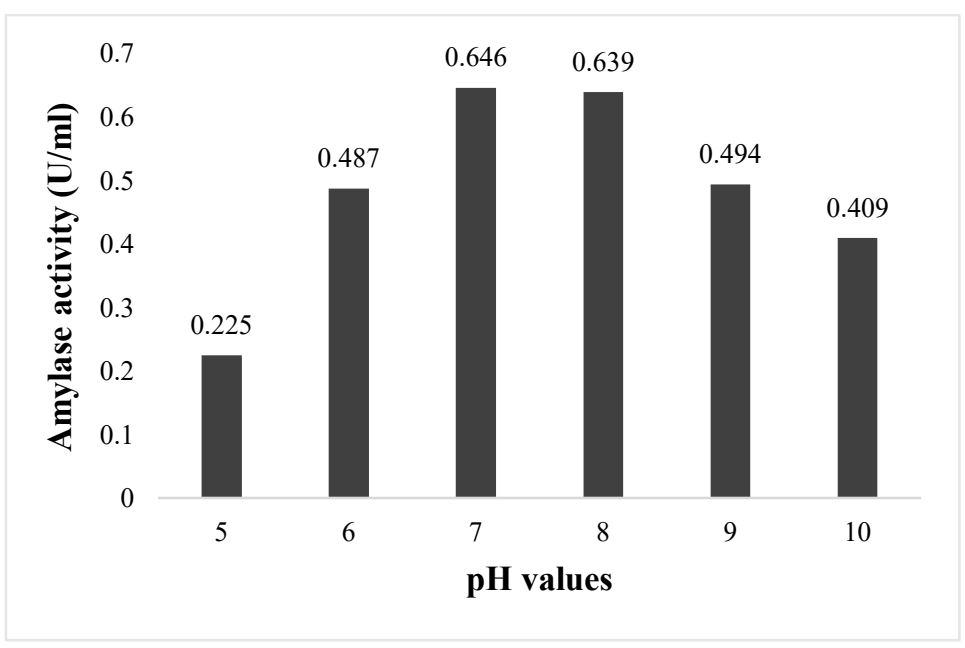

Figure 3. Amylase activity at different $\mathrm{pH}$

Inoculum volume: In our experiment, the enzyme activity was increased as the inoculum volume increases and reached the optimum at $8 \%$ (Fig 4). When the inoculum volume was further increased, the enzyme activity slowly decreased. It may be caused by the initial speedy growth of bacteria and the lack of nutrients in the medium. According to Tsurikova et al., the optimal inoculum volume for the production of amylase was found to be $8 \%$ [26]. Our experiment repeated the results regarding the negative effects of high inoculum volume on amylase production of bacteria [27]. 


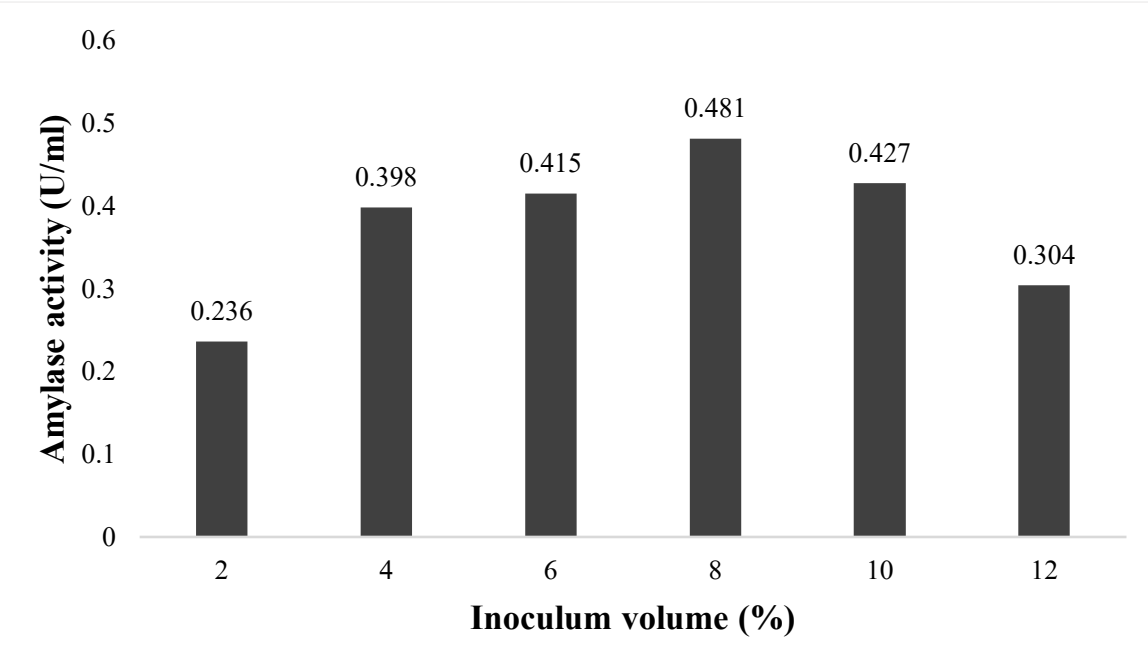

Figure 4. Amylase activity at different inoculum volume

Carbon Source: The effect of carbon sources on amylase production was determined by substituting the carbon sources of the basal media and culturing the bacteria in optimum conditions. Starch was revealed as the most suitable carbon source for amylase production by B. subtilis M4 strain (Fig. 5). Amylase is an inducible enzyme and is generally induced in the presence of starch or its hydrolytic product, maltose [28]. The utilization of soluble starch by Bacillus spp. was reported previously [29]. In the media containing lactose, the lowest amylase production was registered. Based on our experimental data, starch was supposed as the most suitable carbon source for $B$. subtilis M4 for amylase production.

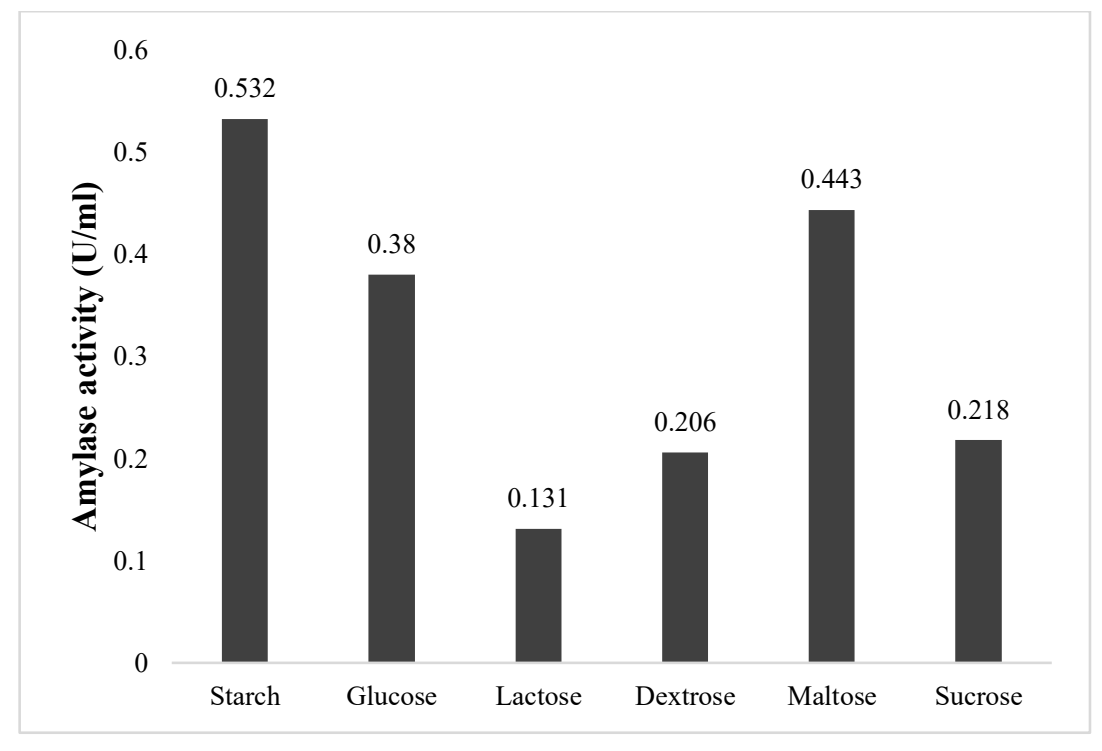

Figure 5. Amylase activity at different carbon sources

Nitrogen Sources: To determine the effect of nitrogen sources on amylase production we used different organic nitrogen sources with basal media. In the media containing peptone, the highest amylase production was recorded. Ammonium sulfate was revealed as the least suitable nitrogen source.
According to our study, the B. subtilis M4 strain produced 6-fold more amylase in the media with peptone with comparing with ammonium sulfate (Fig. 6). Tryptone, peptone, and casein were registered as suitable sources for the production of amylase [30]. 


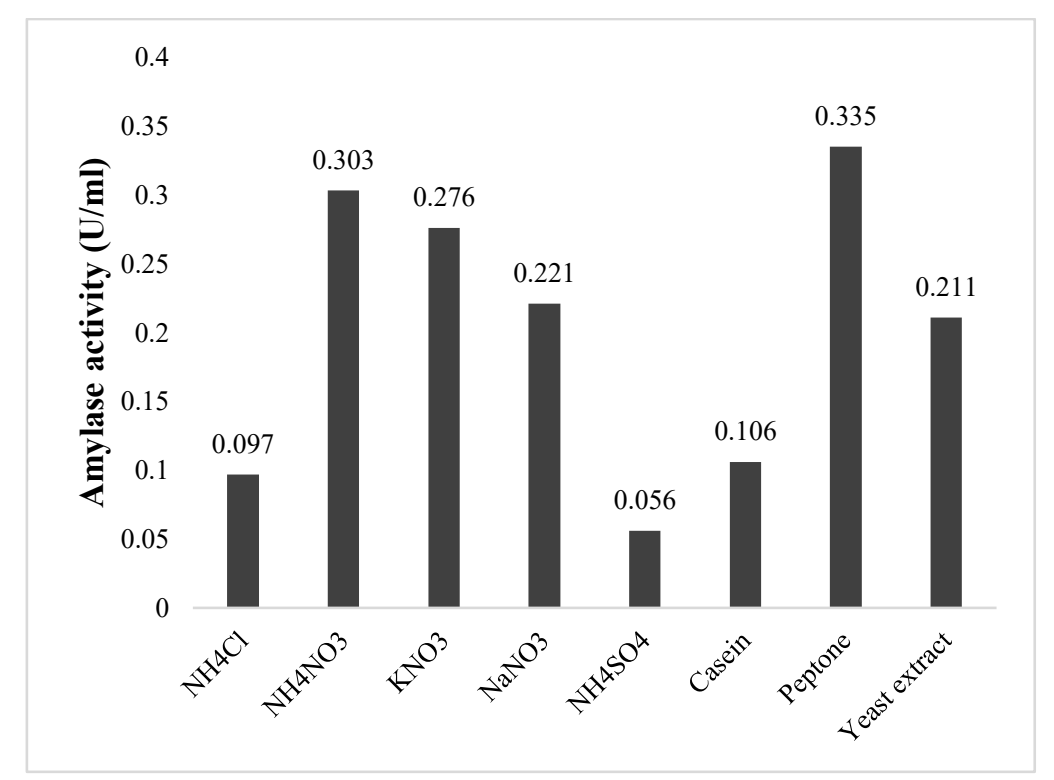

Figure 6. Amylase activity at different nitrogen sources

Chlorides: We have found that calcium chloride affects the highest amylase production and potassium chloride is the second suitable chloride for B.subtilis M4 (Fig 7). The addition of salts of some metal ions resulted in good growth of microorganisms and so better enzyme production (most $\alpha$-amylases are recognized as metalloenzymes). $\mathrm{Ca}^{2+}$ ions are revealed being present in the majority of these enzymes. The addition of $\mathrm{CaCl}_{2}$ to the culture media enhanced enzyme production [31].

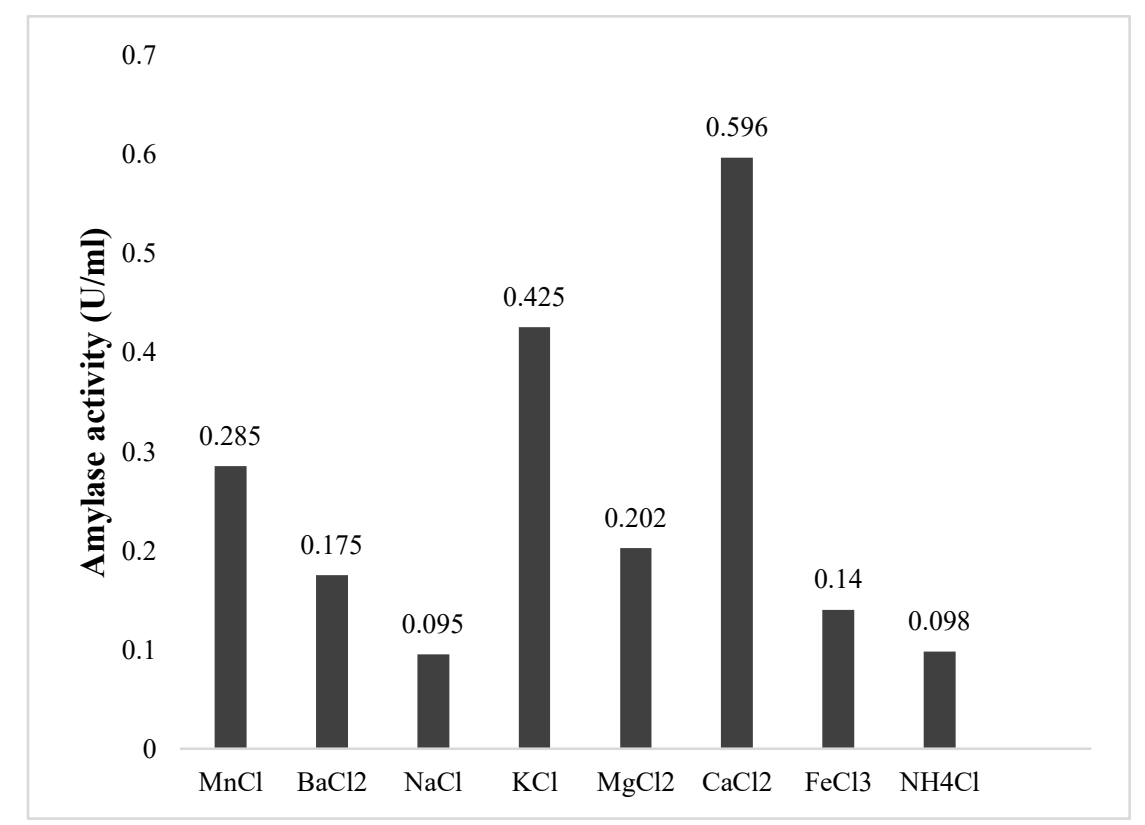

Figure 7. Amylase activity at different chlorides

Sulfates: In our study, calcium sulfate was registered as the best sulfate source for amylase production (Fig 8 ). The next one was found to be magnesium sulfate. $\mathrm{Mg}^{2+}$ had a great role and enzyme production was decreased to $50 \%$ when $\mathrm{Mg}^{2+}$ was eliminated from the medium. $\mathrm{Na}^{+}$and $\mathrm{Mg}^{2+}$ jointly stimulated enzyme production by Bacillus spp. CRP strain [32]. 


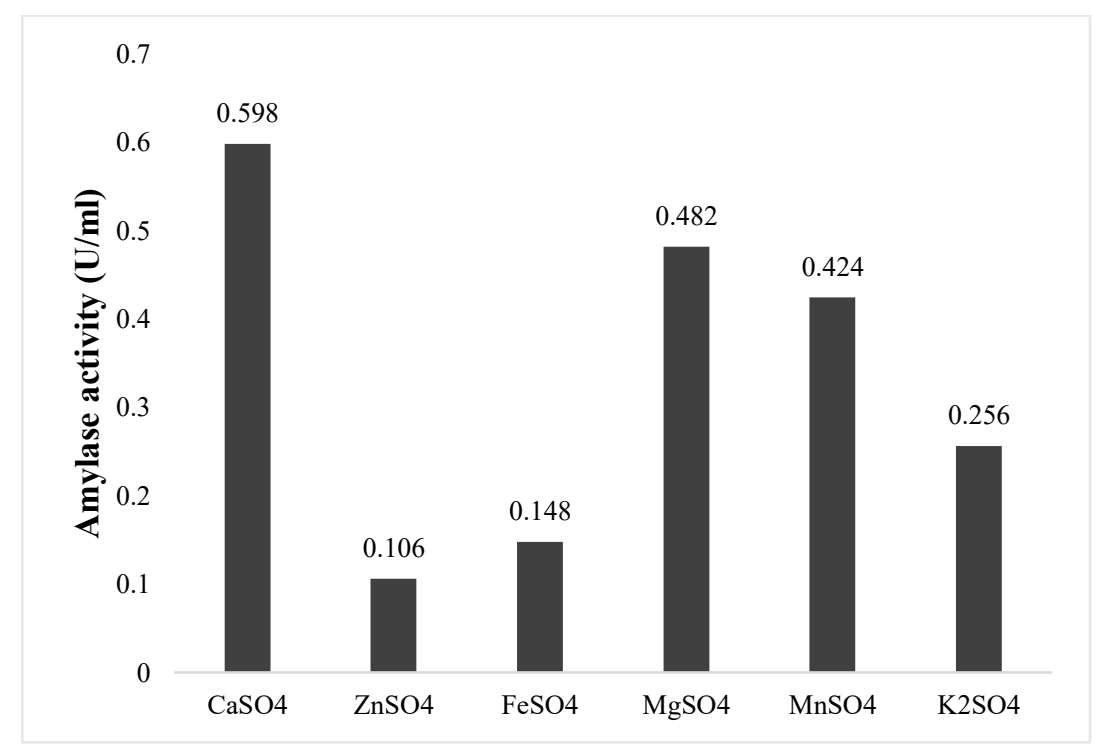

Figure 8. Amylase activity at different sulfates

Phosphates and carbonates: From different phosphates, monopotassium phosphate highly stimulated amylase production by B.subtilis M4 (Fig 9). Phosphate has a significant regulatory role in the synthesis of primary and secondary metabolites in microorganisms [33] and affects the growth of the organism and amylase production. Above $0.2 \mathrm{M}$ phosphate levels significantly increased enzyme production and conidiation in A. oryzae [34]. In this experiment, calcium carbonate greatly increased the production of amylase (Fig. 9), so we defined it to be the best calcium source for $B$. subtilis M4 strain for amylase production.

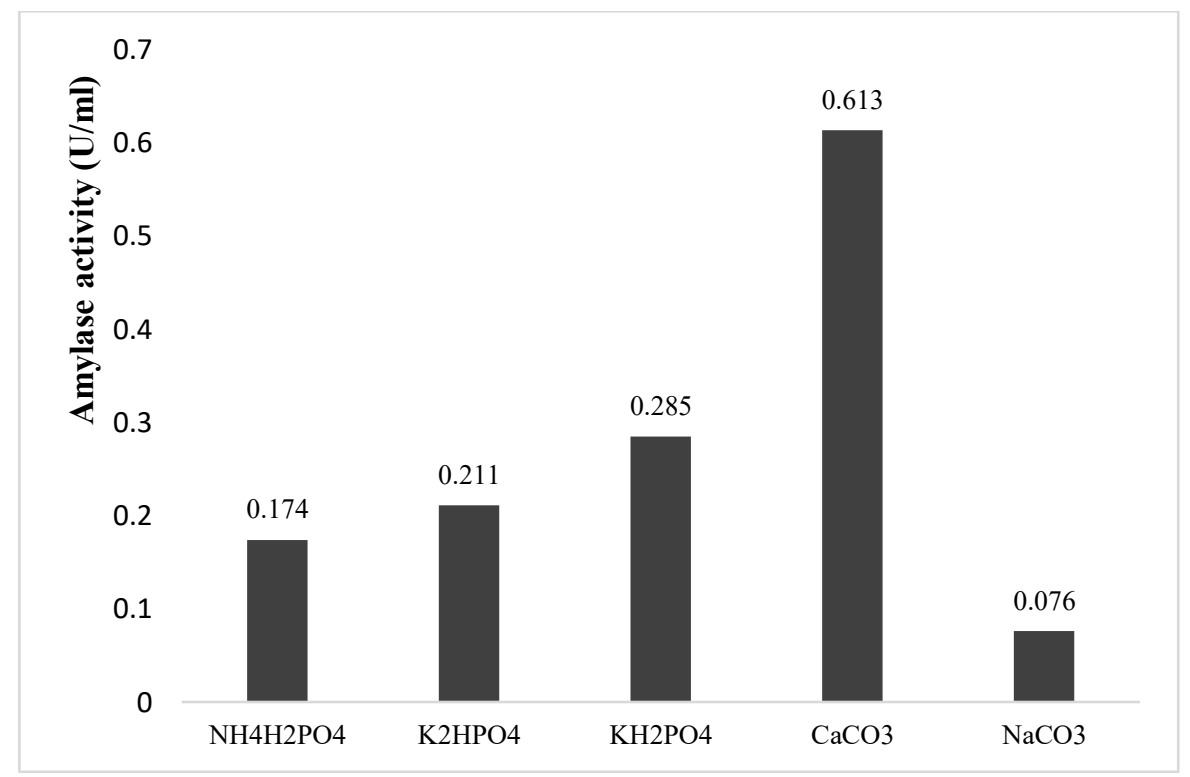

Figure 9. Amylase activity at different phosphates and carbonates

\section{Central composite design (CCD)}

We have determined the effect of the selected 5 variables on amylase activity by the response surface methodology. CCRD matrix with experimental and predicted data are described in Table.2. Amylase activity was identified as the response, starch, peptone, calcium carbonate, magnesium sulfate, and potassium chloride were taken as factors impacting amylase production of $B$. subtilis M4 strain. 
CCRD and Experimental Data for RSM

\begin{tabular}{|c|c|c|c|c|c|c|c|}
\hline \multirow{2}{*}{$\begin{array}{c}\text { Run } \\
\text { № }\end{array}$} & \multirow{2}{*}{$\mathrm{X} 1$} & \multirow{2}{*}{$\mathrm{X} 2$} & \multirow{2}{*}{$\mathrm{X} 3$} & \multirow{2}{*}{$\mathrm{X} 4$} & \multirow{2}{*}{$\mathrm{X} 5$} & \multicolumn{2}{|c|}{ Amylase activity (U/ml) } \\
\hline & & & & & & Experimental* & Predicted \\
\hline 1 & -1 & -1 & -1 & -1 & 1 & 0.960 & 0.952 \\
\hline 2 & 1 & -1 & -1 & -1 & -1 & 1.160 & 1.162 \\
\hline 3 & -1 & 1 & -1 & -1 & -1 & 1.235 & 1.245 \\
\hline 4 & 1 & 1 & -1 & -1 & 1 & 1.059 & 1.020 \\
\hline 5 & -1 & -1 & 1 & -1 & -1 & 1.315 & 1.285 \\
\hline 6 & 1 & -1 & 1 & -1 & 1 & 1.469 & 1.391 \\
\hline 7 & -1 & 1 & 1 & -1 & 1 & 1.399 & 1.330 \\
\hline 8 & 1 & 1 & 1 & -1 & -1 & 0.956 & 0.896 \\
\hline 9 & -1 & -1 & -1 & 1 & -1 & 1.163 & 1.202 \\
\hline 10 & 1 & -1 & -1 & 1 & 1 & 1.045 & 1.035 \\
\hline 11 & -1 & 1 & -1 & 1 & 1 & 0.851 & 0.850 \\
\hline 12 & 1 & 1 & -1 & 1 & -1 & 1.117 & 1.124 \\
\hline 13 & -1 & -1 & 1 & 1 & 1 & 1.172 & 1.132 \\
\hline 14 & 1 & -1 & 1 & 1 & -1 & 1.187 & 1.156 \\
\hline 15 & -1 & 1 & 1 & 1 & -1 & 1.380 & 1.357 \\
\hline 16 & 1 & 1 & 1 & 1 & 1 & 1.032 & 0.961 \\
\hline 17 & -2 & 0 & 0 & 0 & 0 & 1.335 & 1.346 \\
\hline 18 & 2 & 0 & 0 & 0 & 0 & 1.104 & 1.194 \\
\hline 19 & 0 & -2 & 0 & 0 & 0 & 1.358 & 1.386 \\
\hline 20 & 0 & 2 & 0 & 0 & 0 & 1.180 & 1.253 \\
\hline 21 & 0 & 0 & -2 & 0 & 0 & 1.013 & 0.963 \\
\hline 22 & 0 & 0 & 2 & 0 & 0 & 1.041 & 1.192 \\
\hline 23 & 0 & 0 & 0 & -2 & 0 & 1.262 & 1.348 \\
\hline 24 & 0 & 0 & 0 & 2 & 0 & 1.217 & 1.232 \\
\hline 25 & 0 & 0 & 0 & 0 & -2 & 1.207 & 1.200 \\
\hline 26 & 0 & 0 & 0 & 0 & 2 & 0.902 & 1.010 \\
\hline 27 & 0 & 0 & 0 & 0 & 0 & 1.546 & 1.537 \\
\hline 28 & 0 & 0 & 0 & 0 & 0 & 1.549 & 1.537 \\
\hline 29 & 0 & 0 & 0 & 0 & 0 & 1.557 & 1.537 \\
\hline 30 & 0 & 0 & 0 & 0 & 0 & 1.598 & 1.537 \\
\hline 31 & 0 & 0 & 0 & 0 & 0 & 1.547 & 1.537 \\
\hline 32 & 0 & 0 & 0 & 0 & 0 & 1.527 & 1.537 \\
\hline
\end{tabular}

Table 2.

*The observed data of amylase activity are the average of triple experiments The secondary order polynomial equation (2) is the following:

$$
\begin{aligned}
& \mathrm{Y}=1.5373 \quad-0.0380 \mathrm{X} 1 \quad-0.0333 \mathrm{X} 2 \quad+0.0574 \mathrm{X} 3 \\
& -0.0290 \mathrm{X} 4-0.0473 \mathrm{X} 5-0.0668 \mathrm{X} 1 * \mathrm{X} 1 \\
& -0.0545 \mathrm{X} 2 * \mathrm{X} 2-0.1150 \mathrm{X} 3 * \mathrm{X} 3-0.0619 \mathrm{X} 4 * \mathrm{X} 4-0.1081 \mathrm{X} 5 * \mathrm{X} 5-0.0596 \mathrm{X} 1 * \mathrm{X} 2 \\
& -0.0496 \mathrm{X} 1 * \mathrm{X} 3+0.0050 \mathrm{X} 1 * \mathrm{X} 4+0.0559 \mathrm{X} 1 * \mathrm{X} 5 \quad-0.0193 \mathrm{X} 2 * \mathrm{X} 3 \\
& +0.0042 \mathrm{X} 2 * \mathrm{X} 4 \quad-0.0104 \mathrm{X} 2 * \mathrm{X} 5 \quad-0.0080 \mathrm{X} 3 * \mathrm{X} 4 \quad+0.0621 \mathrm{X} 3 * \mathrm{X} 5 \\
& -0.0605 \mathrm{X} 4 * \mathrm{X} 5(2)
\end{aligned}
$$

The calculated response surface for the most important factors is demonstrated by CCRD in a 3dimensional graph (Fig. 10). 3-dimensional graph of starch and peptone (A), calcium carbonate and magnesium sulfate (B), starch and potassium chloride (C) against amylase activity demonstrate the outcomes of the statistical and mathematical analyses.
According our study the optimum concentrations of selected factors were as following (Fig. 11): starch $0.42(12.9 \mathrm{~g} / \mathrm{l})$, peptone $-0.10(9.75 \mathrm{~g} / \mathrm{l})$, calcium carbonate $0.30(0.439 \mathrm{~g} / \mathrm{l})$, magnesium sulfate -0.18 $(0.464 \mathrm{~g} / 1)$, potassium chloride $-0.18(0.464 \mathrm{~g} / 1)$, respectively. At this optimized condition, our model predicted $1.563 \mathrm{U} / \mathrm{ml}$ of amylase activity. 
A

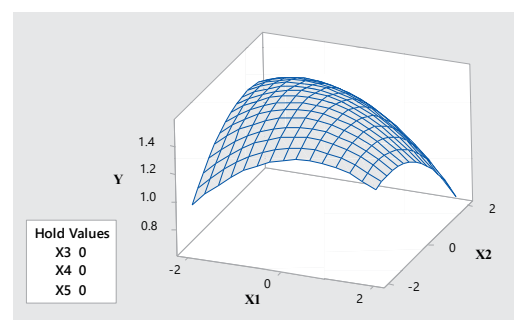

$\mathrm{B}$

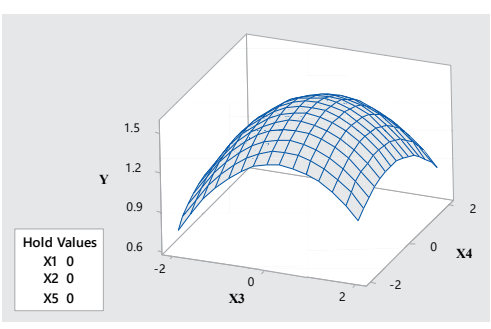

$\mathrm{C}$

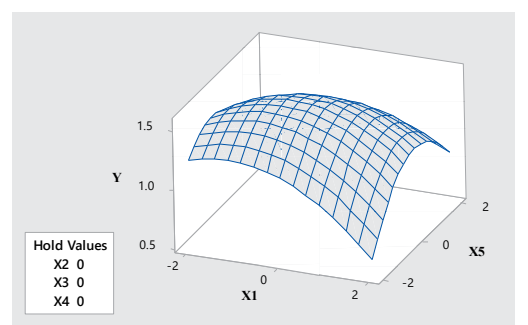

Figure. 10. Three-dimensional graph for amylase production: A unction of starch and peptone(A), calcium carbonate and magnesium sulfate (B), starch and potassium chloride(C)

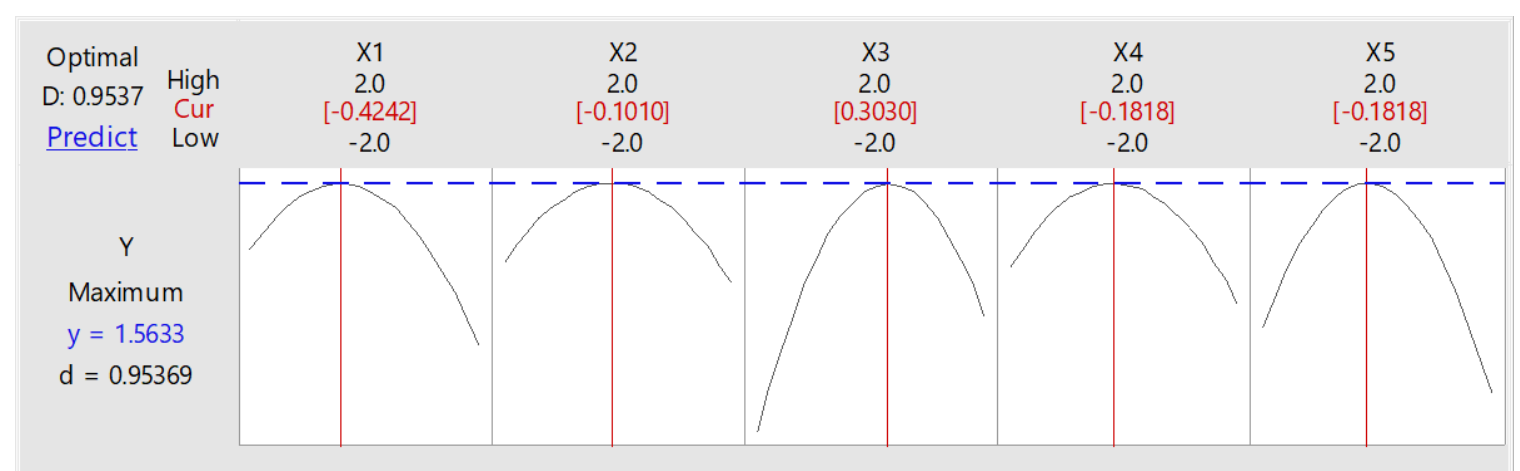

Figure 11. The optimum concentrations of selected factors, founded by solving the secondary order polynomial equation (2)

\section{Comparison between basal and optimized media}

Fig.11 describes changes of amylase production (A), cell density (B), and $\mathrm{pH}(\mathrm{C})$ during the incubation period of B. subtilis M4 in the optimized and basal medium. Cells grew more and reached the highest level at $72 \mathrm{~h}$ of incubation, then the growth reduced slightly. The bacterial growth kept stable after $48 \mathrm{~h}$ of cultivation. The culture broth $\mathrm{pH}$ during the cultivation was between 6.5-7.5. In the optimized medium, the enzyme activity increased from 0.741 to
$1.58 \mathrm{U} / \mathrm{ml}$, which means a 2.1 fold. According to Deljou and Arezi, in the result of medium optimization, amylase production by $B$. licheniformisAZ2 increased by 2.4 fold [11]. Another study reports that for optimization of the fermentation medium components and environmental factors was used OFAT approach and Plackett-Burman design. As a result of this work amylase production by Bacillus lichineformis AH214, was enhanced 2.0 fold compared to the original medium [35].
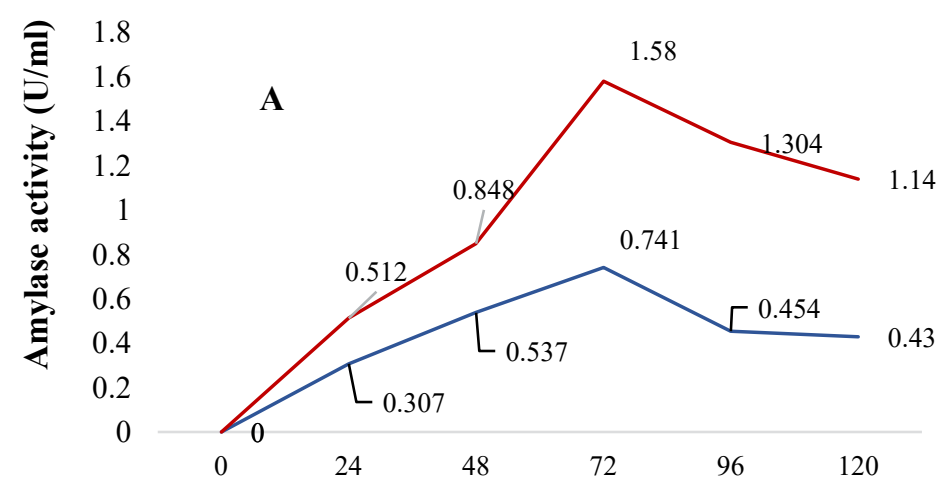

Time (h) 

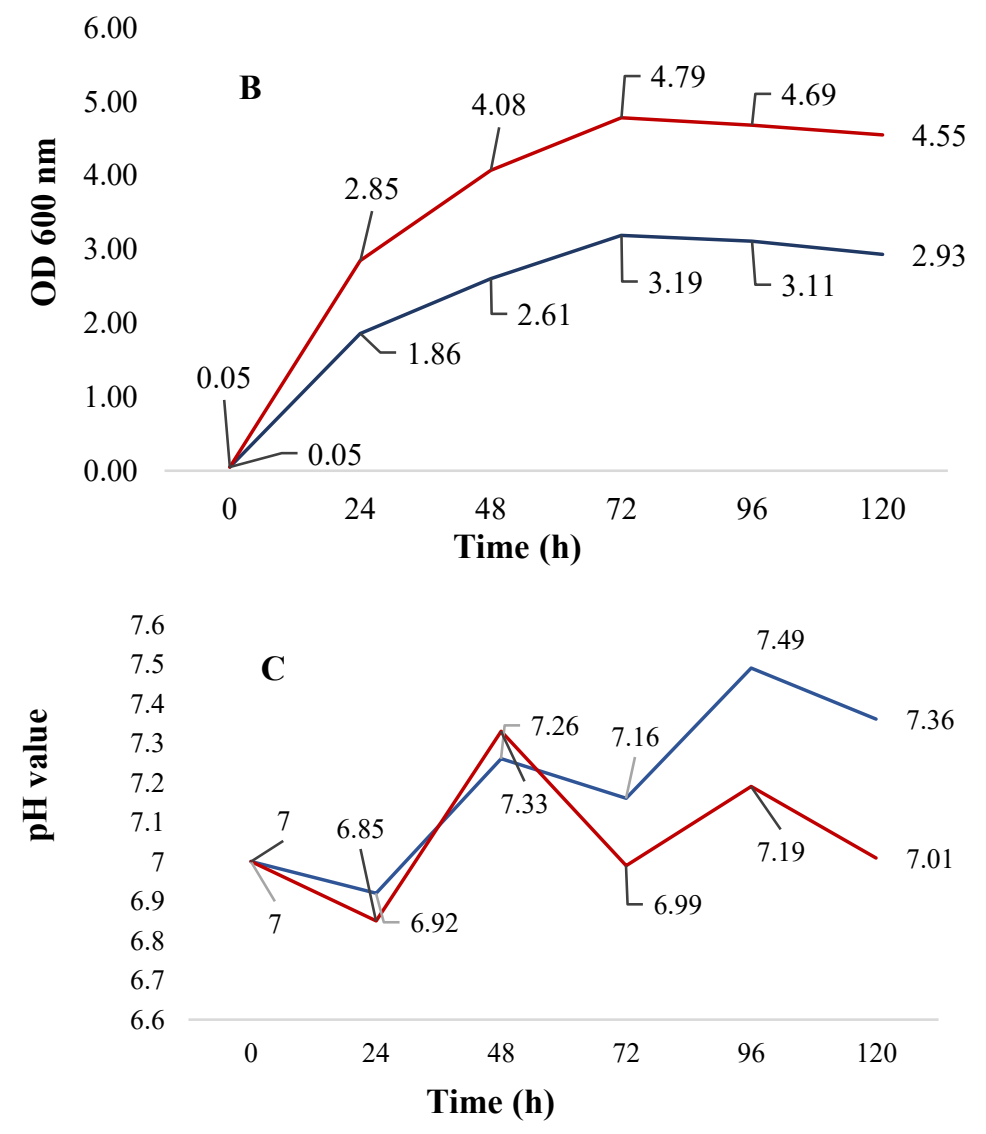

Figure.12.Change in amylase production (A), cell density(B), and $\mathrm{pH}(\mathrm{C})$ during fermentation of B.subtilis M4. Optimized medium (-----)and basalmedium (-----). Each data states the mean of triple independent assays (the standard errors were less than $5 \%$ of the means).

\section{CONCLUSION}

In this study, we aimed to increase the amylase production by the $B$. subtilis M4 mutant strain. For this purpose, the cultural conditions and medium ingredients were optimized by one factor at a time approach and response surface methodology. The optimal culture conditions for amylase production were the following: temperature $35^{\circ} \mathrm{C}, \mathrm{pH}$ value 7 , incubation time $72 \mathrm{~h}$, inoculum volume $8 \%(\mathrm{v} / \mathrm{v})$. Optimal fermentation medium for amylase production contained starch 12.9, peptone 9.75, calcium carbonate 0.439 , magnesium sulfate 0.464 and potassium chloride $0.464 \mathrm{~g} / \mathrm{l}$. In the optimized fermentation media, the enzyme activity reached 1.58 $\mathrm{U} / \mathrm{ml}$, which means a 2.1 fold compared to the basal medium. To be applied commercially, further study is needed for the improvement of this enzyme production.

\section{ACKNOWLEDGMENTS}

This study was a part of the Ph.D. work and we deeply appreciate all supports from the School of Animal
Science and Biotechnology, Mongolian University of Life Sciences for assisting this research paper. 


\section{REFERENCES}

[1] A. Pandey, P.Nigam, C. R. V. T.Soccol, V. Soccol, D.Singh,R.Mohan,2000, "Advances in microbial amylases,"Biotechnology and Applied Biochemistry, 31:135-152.

[2] M.S. Tanyildizi, D. Ozer, M. Elibol, 2005, "Optimization of $\alpha$-amylase production by Bacillus spp. using response surface methodology,"Process Biochem, 40:22912296.

[3] Md. Mahbub Hasan, Lolo Wal Marzan, Asamul Hosna, Al Hakim, Abul Kalam Azad, 2017, "Optimization of some fermentation conditions for the production of extracellular amylases by using Chryseobacterium and Bacillus isolates from organic kitchen wastes,"Journal of Genetic Engineering and Biotechnology. 15:59-68.

[4] Z. Konsoula, M. Liakopoulou-Kyriakides, 2007, "Co-production of alpha-amylase and beta-galactosidase by Bacillus subtilis in complex organic substrates,"Bioresour Technol, 98:150-157.

[5] N. Boz ic', J. Ruiz, J. Lo'pez-Santı'n, Z. Vujc 'ic', 2011, "Production and properties of the highly efficient raw starch digesting aamylase from a Bacillus licheniformis ATCC 9945a," Biochem. Eng. J, 53:203-209.

[6] C. Renata Pascon, Rogério Faria Bergamo, Rafael Xavier Spinelli, Elisangela Dutra de Souza, Diego Magno Assis, Luiz Juliano and Marcelo Afonso Vallim, 2009, "Amylolytic Microorganism from São Paulo Zoo Composting: Isolation, Identification, and Amylase Production," Brazil.

[7] M. Hanan, Abel-Nabey and Aida M. Farag,2016, "Production, optimization and characterization of extracellular amylase from halophilic Bacillus lichineformis AH214,"African Journal of Biotechnology, 15(17):670-683.

[8] K.R Aneja, 2002, "Experiments in Microbiology, Plant Pathology, Tissue culture and Mushroom Production technology. New age international (P) Ltd., Publishers, 169-171.

[9] E. Fisher, I. Stein, 1961, " $\alpha$-amylase from human saliva,"Biochem. Prep, 8:27-33.

[10] GL. Miller, 1959, "Use of Dinitro salicylic acid reagent for determination of reducing sugar," Anal. Chem. 31:426-429.

[11] Ali Deljou and Iman Arezi, 2016, "Production of thermostable extracellular a-amylase by a moderate thermophilic Bacillus licheniformisAZ2 isolated from Qinarje Hot spring (Ardebil prov. of Iran),"Periodicum Biologorum, 118(4):405-416.

[12] PV. Dharani Aiyer, 2004, "Effect of C:N ratio on alpha amylase production by Bacillus licheniformis SPT 27,"Afr. J. Biotechnol. 3(10):519-522.

[13] Shieh, C.-J., C.C. Akoh, and L.N. Yee, 1996, Optimized Enzymatic Synthesis of Geranyl Butyrate with Lipase AY from Candida rugosa, Biotechnol. Bioeng. 51:371-374.

[14] Cochran, W.G., and G.M. Cox, 1992, Experimental Designs, John Wiley \& Son, Inc., New York.

[15] K. Ashwini, Gaurav Kumar, L. Karthik, K.V. Bhaskara Rao,2100, "Optimization, production and partial purification of extracellular $\alpha$ amylase from Bacillus spp.marini," Arch. Appl. Sci. Res., 3(1): 33-42.

[16] SAS, SAS User's Guide, SAS Institute, Inc., Cary, NC, 1990.

[17] F. G. Moreira, F. A. de Lima, S.R. Fazzano Pedrinho, V. Lenartovicz, C. Giatti, M. de Souza, R.M. Peralta, 1999, "Production of amylases by Aspergillus tamari,"Revista de Microbiologia, 30:157-162.

[18] Dibu Divakaran, Aswathi Chandran, R. Pratap Chandran, 2011, "Comparative study on production of $\alpha$-amylase from Bacillus licheniformis strains,"Brazilian Journal of Microbiology, 42:1397-1404, ISSN 15178382.

[19] S. Thippeswamy, K. Girigowda, V.H.Mulimani, 2006, "Isolation and identification of alpha-amylase producing Bacillus spp. from dhal industry waste,"Indian Journal of Biochemistry and Biophysics, 43 (5):295.

[20] Sasmita Mishra and Niranjan Behera, 2008, "Amylase activity of a starch degrading bacteria isolated from soil receiving kitchen wastes,"African Journal of Biotechnology,7 (18):3326-3331.

[21] C. Krishna and M Chandrasekaran, 1996, "Banana waste as substrate for $\alpha$-amylase production by Bacillus subtilis(CBTK-106) under solid state fermentation,"Appl. Microbiol. Biotechnol., 46: 106-11.

[22] Bharat Pokhrel, Priyesh Wanjare, Suman Singh, B. Purushotham and M. Kumara Swamy, 2013, "Isolation, screening and characterization of promising $\alpha$-amylase producing bacteria from sewage enriched 
soil,"International Journal of advanced Biotechnology and research, 4(2):286-290.

[23] D. Divakaran, A. Chandran, R. Pratap, Chandran, 2011, Braz. J. Microbiol. 42 (4), 1397-1404.

[24] A. Behal, J. Singh, MK. Sharma, P. Puri, N. Batra,2006, Int J Agri Biol, 8:80-83.

[25] A. Sumrin, W. Ahmad, B. Ijaz, MT. Sarwar, S. Gull, H. Kausar, I. Shahid, S. Jahan, S. Asad, M. Hussain, S. Riazuddin, 2011, African J Biotech, 10:2119-2129.

[26] N.V. Tsurikova, L.I. Nefedova, E.V. Kostyleva, V.I. Zvenigorodskii, V.G. Iasinovskiı̆, T.A. Voě̌kova and A.P. Sinitsyn,2002, Prikle Biokhimical Mikrobiology, 38:502-508.

[27] N. Riaz, I. Ul-Haq, M.A. Qadeer, 2003, "Characterization of amylase by Bacillus subtilis,"Int. J. Agric. Biol., 5:249-252.

[28] K. Tonomura, H. Suzuki, N. Nakamura, K. Kuraya, O. Tanabe, 1961, "On the inducers of a-amylase formation in Aspergillus oryzae,"Agric Biol Chem. 25:1-6.

[29] R.K. Saxena, K. Dutt, L. Agarwal, P.Nayyar, Bioresour.2007,Technol. 98 (2) 260-265.
[30] N. Sharma, R. Vamil, S. Ahmad, R. Agnihotri, 2012, Int. J. Pharm. Sci. Res. 3 (4):1161.

[31] F. Francis, A. Sabu, K.M. Nampoothiri, S. Ramachandran, S. Ghosh, G. Szakacs, A. Pandey,2003, Biochem. Eng. J, 15:107-115.

[32] W.X. Wu, J. Mabinadji, T.F. Betrand and W.X. Wu, 1999, "Effect of culture conditions on the production of an extracellular thermostable alpha-amylase from an isolate of Bacillus sp, $J$ Zhejiang Univ Agric Life Sci. 25:404-8.

[33] A.C.R Dean, 1972, "Influence of environment on the control of enzyme synthesis," $J \mathrm{Appl}$ Chem Biotechnol. 22:245-59.

[34] S. Ueno, M. Miyama, Y. Ohashi, M. Izumiya, I. Kusaka, 1987, "Secretory enzyme production and conidiation of Aspergillus oryzae in submerged liquid culture,"Appl Microbiol Biotechnol. 26(3):273-276.

[35] M. HananAbel-Nabey and M. AidaFarag, 2016, "Production, optimization and characterization of extracellular amylase from halophilic Bacilluslichineformis AH214," Afr. J. Biotechnol. 15(17):670-683. 